\title{
YouTube Music as an Innovative Teaching Media to Improve Students' Listening Mastery
}

\author{
Izza Amalia Rahman*, Mutmainnah Mustofa, Izzatin Nisa' \\ Master of English Language Teaching, Post Graduate Program, University of Islam Malang \\ *Corresponding Author. Email: izzaakaizvi@gmail.com
}

\begin{abstract}
This research aims to investigate the effectiveness of YouTube Music platform as teaching media to improve students' listening mastery. It is believed that YouTube Music as an innovative media could be used effectively to attract students' interest in increasing their listening mastery. By using trueexperimental research with quantitative design, there are 52 students were divided into two groups, 26 students for experimental group and 26 students included in control group. This research used test and questionnaire as research instrument. There are several findings to prove that YouTube Music platform is an effective media to improve students' listening skills. By conducting test as first instrument, it was found that the average score of students taught by YouTube music was 79.85. It was higher than those who taught by conventional media (71.50). By analyzing the data, it can be concluded that there are significant different between students taught by innovative media than those taught by conventional media. This result also affected by students' perception in learning listening which was found by students' answer from questionnaire.
\end{abstract}

\author{
Article History \\ Received: 13-11-2021 \\ Revised: 01-12-2021 \\ Accepted: 07-12-2021 \\ Published: 07-01-2022
}

\section{Key Words:}

Teaching Media, Youtube Music, Listening

Mastery.

How to Cite: Rahman, I., Mustofa, M., \& Nisa', I. (2022). YouTube Music as an Innovative Teaching Media to Improve Students' Listening Mastery. Jurnal Paedagogy, 9(1), 8-16. doi:https://doi.org/10.33394/jp.v9i1.4402 do]

This is an open-access article under the CC-BY-SA License.

\section{Introduction}

Nowadays, various teaching medias appear in order to help increasing students' ability in EFL learning. Several new electronic medias are started to be used and the traditional has been left one by one. Modern devices such as mobile phone, PC or laptop, television, and the internet are tools that cannot be separated from students' lives. In addition, social medias also take a part on it. It is proved with a study conducted by Pradipta and Mustofa (2020) which said that Smart TV has significance to increase students' understanding. From that fact, it is a common issue that EFL teachers need to use potentially valuable technologies to enhance students' capability.

Listening is one of the crucial skills in EFL learning that often causes difficulties for the students to master it. Sometimes, it is effortful for them to comprehend the listening context. Listening, according to Rost (2013) is the ability to recognize what others are saying. Furthermore, Nihei (2002) stated that listening is a vital skill for someone who learns English because people cannot communicate well without listening to and understanding the speaker's utterances. Also according to Hasyuni (2006), listening is a creative skill. Understanding the sound that falls on our ears, word arrangements, the rise and fall of the voice, and deriving meaning from this material. We must frequently listen to individuals who speak English, as a reason for the communicating, watching movie, and listen to music in order to increase English skill. For the EFL teachers, teaching listening can be very challenging. They have to use appropriate media so that the students follow them in a good way. The use of good media also makes students increase their interest in learning. Previous researches believed that YouTube is one of good media to improve students' listening skills. 
According to Lee \& Liang (2012) stated at Al Jawad \& Mansour (2021), YouTube is a video-sharing website that allows its users from all universe to watch videos made by others and to contribute their own videos. It covers educational, entertainments, political, medical, historical, and even personal videos, among others. YouTube videos can be used as media in language learning. As previously said, YouTube is a widely available source of information. It encourages students to connect the popular and modern culture in an educational capacity through English language. YouTube may serve as a motivator for students who want to improve their language abilities by learning more about the stuff they freely access online with visiting the website or installing the application. It is also possible for students to engage in some type of student-centered learning outside of the class activities (Kreisen, 2009; Mostajeran \& Tabatabaei, 2019).

Besides YouTube Video, the newest branch of YouTube platform is YouTube Music. YouTube Music is a music streaming service created by Google's YouTube division. It offers a customized interface for the service that is geared for music streaming, letting users to search for songs and music videos on YouTube using genres, playlist, and recommendations. It can be used for more specific listening practice such as comprehending song lyrics. YouTube Music provides more than 70 million official songs, music content including live performances, song covers, song remixes, and also thousands of curated playlists across many genres and activities. YouTube Music enhances our listening experiences with unique features such as song lyrics, switch seamlessly between audio and video, and we can listen on our phone, smart speaker, smart TV, smart watch, or car. It also compatible with Google Maps, Waze, Google Assistant, and more. It can be accessed freely or premium.

YouTube platform and application are commonly used for education. Teachers from all around the world have been implemented this platform as a teaching media. Teachers take materials or even create their own YouTube channel. It has potential for online instructional usage, as it has been studied by a number of researchers, including (Burke \& Synder, 2008; Alimemaj, 2010; Al Jawad \& Mansour, 2021). YouTube is a great source of culturally genuine resources that can encourage students to interact with popular cultures in an educational capacity via English language videos or music. YouTube music and videos have some advantages for learning language in providing authentic examples about the use of English for daily conversations by native speakers. Besides, the YouTube music and videos can be used as tools to improve language skills including listening, speaking, reading and writing. According to Khalid and Muhammad (2012), using YouTube in the classroom can help students understand the material better. Meanwhile, YouTube can be utilized to increase vocabulary, accents, pronunciations, listening, reading, writing, and speaking in English (Chhabra, 2012).

Nowadays, many EFL students watch and listen many kinds of videos or music on YouTube. Although may of them watch videos and listen to music on YouTube, few perceive it as an opportunity to improve their listening skills. If teachers can correctly integrate YouTube into classroom, learning English will become more creative.

Several researchers have discussed about YouTube as a media to improve listening comprehension. There are several previous related studies related to this topic. Al Jawad \& Mansour (2021) have discussed about "The Significance of Using YouTube as an Academic Tool to Improve Students' Listening Skill in Libyan Universities”. This study found that YouTube videos increase students' interest in improving their listening skills. Besides that, Mostajeran \& Tabatabaei (2019) found that students taught with YouTube videos had significantly better performance that students are not taught with YouTube videos by 
conducting research entitled "Impact of Using YouTube Videos on Iranian Intermediate Male and Female EFL Learners' Listening Skill Development." Different with the previous studies, this research focuses on the newest branch of YouTube that is YouTube Music platform and its role in order to improve students listening mastery especially for junior high school students. Therefore, this research comes with a problem, "Do students taught by YouTube Music have better achievement in listening test than those taught by conventional media?"

Dealing with the improvement of students listening mastery, the researches argue that YouTube Music can be an innovative media to attract students in improving their listening skills. The alternative hypothesis in this research is that using YouTube Music as an innovative media will make students score in listening better than students taught by conventional media. While the null hypothesis suggests that the use of YouTube Music as teaching media does not make a better score in listening just same as the conventional media. This research aims to investigate the effectiveness of YouTube Music as teaching media to improve students' listening mastery. It is important to be studied because it has theoretical significance to give further information about the advantages of YouTube Music platform and for the practical significance, it can be used as alternative media in order to enhance students' listening skills.

\section{Research Method}

This research was a true-experimental research with quantitative approach. In the true-experimental research, there are two selected groups that chosen randomly. One of the groups become experimental group and the other one become the control group (Latief, 2019). The treatment given to the experimental students was the implementation of YouTube Music as teaching media for listening comprehension and for the control students were not given the treatment and only used a conventional media for listening (speaker, sound recording, or teachers' speaking and dictation). The population of this research was seventh grade students of Junior High School Kanjeng Sepuh Sidayu, Gresik on the academic year $2021 / 2022$. The sample of this research was chosen by random sampling and two class that consist of 52 students were selected. 26 students as an experimental group and the other 26 students became the control group.

This research used test and questionnaire as instruments. The test, which was divided into two parts, test for experimental group and test for the control group, was conducted to obtain statistical data. Meanwhile, the questionnaire was administered to find out how the students' responses about their listening ability and learning media that they have got. The procedures of data collection have been divided into several sections. First, to collect data the researchers that acted as the English teacher teach about listening skill in the classroom. The first activity was dividing 52 students into two classes randomly, 26 students concluded to experimental group and the other 26 students were in control group. Second, the teacher gave an innovative media that was a YouTube Music Platform for the experimental group and noninnovative media which was conventional media (speaker or even oral spoken by the teacher) for the control group. Here, the experimental group students could access the songs as much songs as they want. In addition, they also could access the song lyrics. Students can observe the lyrics by themselves so they can easily to comprehend the song. Students in experimental group can get used to listen as often as possible. While for the students from control group, they could not access the audio for listening as much as they want and they could not do relisten activity or even access the material for listening as they want. 
After teaching for about two meetings, the teachers gave the same listening test for both experimental and control group. The teachers gave one song to the students and asked them to repeat their listening activity of the song for several times. After that, the teacher gave several questions to know how the listening skill can be improved and how far they can comprehend the lyrics of the song. Moreover, aside from giving tests, the researchers also distributed questionnaire. The students were asked to answer several questions related to their listening mastery and their learning media. The data analysis in true-experimental research, the researchers compare two different groups (experimental group and control group). After that, the researchers analyze the scores by using software SPSS to compare students' achievement. Independent T-test is applied to compare the achievement of two groups (who were taught by YouTube Music and conventional media).

\section{Results and Discussion}

The Analysis of the Score

This research was conducted in two classes. The test score can be seen in table 1 below.

Table 1. Students Test Score of Listening Skill

\begin{tabular}{|c|c|c|c|c|}
\hline No & $\begin{array}{l}\text { Experimental Group } \\
\text { (YouTube Music) }\end{array}$ & Score & $\begin{array}{c}\text { Control Group } \\
\text { (Conventional Media) }\end{array}$ & Score \\
\hline 1 & A 1 & 75 & C 1 & 70 \\
\hline 2 & A 2 & 80 & C 2 & 78 \\
\hline 3 & A 3 & 77 & C 3 & 67 \\
\hline 4 & A 4 & 74 & $\mathrm{C} 4$ & 72 \\
\hline 5 & A 5 & 81 & C 5 & 68 \\
\hline 6 & A 6 & 72 & C 6 & 74 \\
\hline 7 & A 7 & 75 & C 7 & 65 \\
\hline 8 & A 8 & 85 & C 8 & 67 \\
\hline 9 & A 9 & 87 & C 9 & 77 \\
\hline 10 & A 10 & 80 & C 10 & 72 \\
\hline 11 & A 11 & 79 & C 11 & 69 \\
\hline 12 & A 12 & 76 & C 12 & 69 \\
\hline 13 & A 13 & 82 & C 13 & 85 \\
\hline 14 & A 14 & 80 & C 14 & 68 \\
\hline 15 & A 15 & 88 & C 15 & 75 \\
\hline 16 & A 16 & 82 & C 16 & 69 \\
\hline 17 & A 17 & 77 & C 17 & 68 \\
\hline 18 & A 18 & 83 & C 18 & 72 \\
\hline 19 & A 19 & 78 & C 19 & 64 \\
\hline 20 & A 20 & 88 & C 20 & 67 \\
\hline 21 & A 21 & 76 & C 21 & 75 \\
\hline 22 & A 22 & 80 & C 22 & 74 \\
\hline 23 & A 23 & 83 & C 23 & 77 \\
\hline 24 & A 28 & 80 & C 24 & 70 \\
\hline 25 & A 27 & 86 & C 25 & 69 \\
\hline 26 & A 26 & 72 & C 26 & 78 \\
\hline
\end{tabular}


The table above shows the scores of different groups, experimental group after getting treatment by using YouTube Music and control group by using conventional media. After recapitulating the scores of each student from two different groups, below is a table that shows the average score of each group. The average scores are calculated by using a software called SPSS.

Table 2. The Result of Average Scores by Using SPSS

\begin{tabular}{|ll|r|r|r|r|}
\hline & Listening Media & N & Mean & Std. Deviation & \multicolumn{1}{c|}{$\begin{array}{c}\text { Std. Error } \\
\text { Mean }\end{array}$} \\
\hline Listening_Skill & YouTube Music & 26 & 79.85 & 4.619 & .906 \\
& Conventional Media & 26 & 71.50 & 4.860 & .953 \\
\hline
\end{tabular}

The average score of students taught by YouTube Music is 79.85 while the average score of students taught by conventional media is 71.50 . The Independent T-test is used to see if there is a difference in average score of the test between experimental and control group. The purpose of this test is to verify if the alternative hypothesis is accepted. The scores for both groups are presented in the following table, based on the results of the Independent T-test acquired from SPSS.

Table 3. The Result of Independent T-Test by Using SPSS

\begin{tabular}{|c|c|c|c|c|c|c|c|c|}
\hline \multicolumn{2}{|c|}{$\begin{array}{c}\text { Lemenes Test for Equality of } \\
\text { Variances }\end{array}$} & \multicolumn{7}{|c|}{ ttest for Equality of Means } \\
\hline \multirow[b]{2}{*}{$F$} & \multirow[b]{2}{*}{ Sig. } & \multirow[b]{2}{*}{$t$} & \multirow[b]{2}{*}{ df } & \multirow[b]{2}{*}{ Sig. (2-tailed) } & \multirow{2}{*}{$\begin{array}{c}\text { Mean } \\
\text { Difference } \\
\end{array}$} & \multirow{2}{*}{$\begin{array}{l}\text { Sitd Error } \\
\text { Difference }\end{array}$} & \multicolumn{2}{|c|}{$\begin{array}{l}\text { 95\% Confidence Interval of the } \\
\text { Difference }\end{array}$} \\
\hline & & & & & & & Lower & Upper \\
\hline .138 & .712 & 6.347 & 50 & .000 & 8.346 & 1.315 & 5.705 & 10.987 \\
\hline & & 8.347 & 49.871 & .000 & 8.346 & 1.315 & 5.705 & 10.987 \\
\hline
\end{tabular}

The mean difference is 8.346. By this difference, to know that YouTube channel is effective media or not, the hypothesis should be tested. The result of hypothesis testing is showed in probability value Sig. (2-tailed). Here, the researcher used the level of significance is 0.05 . The following are the rules of hypothesis rejection and acceptance:

1) If Sig. $>0.05$, then the null hypothesis is accepted and the alternative hypothesis is rejected.

2) If Sig. $<0.05$, then the null hypothesis is rejected and the alternative hypothesis is accepted.

From the statistics analysis output above, the column Sig. (2-tailed) for equality of variances indicated as 0.000 , or possibility less than $0.05(0.000<0.05)$, it means that null hypothesis is rejected while the alternative hypothesis is accepted. As a result, we may deduce that the average score of experimental group and control group differs significantly. The average score of the experimental group (79.85) is significantly better than the average score of the control group (71.50).

\section{Analysis of Questionnaire}

The questionnaire was distributed for both experimental and control group to know students' opinion about learning English and listening and also to evaluate whether the teaching listening media effects their listening score or not. The researchers argue that using questionnaire as one of the instruments is also useful because from the students' answer, it 
can be correlated that the students' result of the listening test is affected by their perception in learning English especially listening. The analysis of the questionnaire is presented in the following table.

Table 4. Analysis of Questionnaire

\begin{tabular}{|c|c|c|c|c|c|c|}
\hline No & Statement & $\begin{array}{c}\text { Strongly } \\
\text { Agree }\end{array}$ & Agree & $\begin{array}{c}\text { Slightly } \\
\text { Agree }\end{array}$ & Disagree & $\begin{array}{l}\text { Strongly } \\
\text { Disagree }\end{array}$ \\
\hline 1 & I like English & $6 \%$ & $58 \%$ & $19 \%$ & $17 \%$ & $0 \%$ \\
\hline 2 & I like listening & $10 \%$ & $59 \%$ & $8 \%$ & $23 \%$ & $0 \%$ \\
\hline 3 & $\begin{array}{l}\text { I feel easy to learn } \\
\text { listening }\end{array}$ & $8 \%$ & $52 \%$ & $29 \%$ & $11 \%$ & $0 \%$ \\
\hline 4 & $\begin{array}{l}\text { I like the teaching } \\
\text { method }\end{array}$ & $27 \%$ & $62 \%$ & $11 \%$ & $0 \%$ & $0 \%$ \\
\hline 5 & $\begin{array}{l}\text { I always satisfy } \\
\text { with the learning } \\
\text { media }\end{array}$ & $2 \%$ & $81 \%$ & $17 \%$ & $0 \%$ & $0 \%$ \\
\hline 6 & $\begin{array}{l}\text { I am good at } \\
\text { vocabulary and } \\
\text { analyzing sounds }\end{array}$ & $6 \%$ & $54 \%$ & $36 \%$ & $4 \%$ & $0 \%$ \\
\hline 7 & $\begin{array}{l}\text { I always try to } \\
\text { increase my } \\
\text { listening skill }\end{array}$ & $19 \%$ & $63 \%$ & $2 \%$ & $12 \%$ & $4 \%$ \\
\hline 8 & $\begin{array}{l}\text { I get a lot of } \\
\text { motivation during } \\
\text { learning }\end{array}$ & $27 \%$ & $50 \%$ & $8 \%$ & $15 \%$ & $0 \%$ \\
\hline 9 & $\begin{array}{l}\text { I understand with } \\
\text { the lesson from } \\
\text { teacher }\end{array}$ & $15 \%$ & $71 \%$ & $4 \%$ & $10 \%$ & $0 \%$ \\
\hline 10 & $\begin{array}{l}\text { I always ready for } \\
\text { learning }\end{array}$ & $31 \%$ & $54 \%$ & $9 \%$ & $6 \%$ & $0 \%$ \\
\hline 11 & $\begin{array}{l}\text { I like listening to } \\
\text { music at home }\end{array}$ & $17 \%$ & $52 \%$ & $25 \%$ & $6 \%$ & $0 \%$ \\
\hline 12 & $\begin{array}{l}\text { I am confident with } \\
\text { my listening skill }\end{array}$ & $13 \%$ & $60 \%$ & $19 \%$ & $8 \%$ & $0 \%$ \\
\hline 13 & $\begin{array}{l}\text { I always get correct } \\
\text { answer in listening } \\
\text { test }\end{array}$ & $8 \%$ & $42 \%$ & $38 \%$ & $12 \%$ & $0 \%$ \\
\hline 14 & $\begin{array}{l}\text { Learning media } \\
\text { affects my listening } \\
\text { skill }\end{array}$ & $9 \%$ & $81 \%$ & $4 \%$ & $6 \%$ & $0 \%$ \\
\hline 15 & $\begin{array}{l}\text { I always do } \\
\text { listening assignment } \\
\text { as good as possible }\end{array}$ & $15 \%$ & $63 \%$ & $19 \%$ & $0 \%$ & $4 \%$ \\
\hline
\end{tabular}

From the previous table, the researchers can infer that there are various perceptions toward English learning, especially listening and the teaching media that affect students' score in listening test. Most of students agree that they do not really feel difficult in learning listening and most of them also agree that the teaching media is satisfied them in learning 
process. It means that both of experimental group and control group have almost the same opinion. However, related to the score of the listening test, the students from the control group get lower score than students from experimental group. It indicates that the more effective media used in teaching listening is the media that has been used in experimental group which is YouTube Music. It was proved by Saputra (2018) that when students taught by YouTube, they became more enthusiast and interest with listening content. As a result, listening is no longer an uninteresting subject. YouTube contents provide a wealth of knowledge, new vocabulary, and other variety of English to help them in enhancing their listening proficiency.

\section{Discussion}

Depends on the research findings above, YouTube Music platform is the media that makes students' score better in listening. It means that YouTube Music could enhance students' listening mastery. It was proven by the average score of students taught by YouTube Music was higher than students taught by conventional media. It indicates that this platform is suggested to be used in educational field. Al Jawad \& Mansour (2021) stated that YouTube is a great source of contextually genuine resources that could also inspire students to engage with various genres of culture in an educational context through English language content.

This research findings present that YouTube Music is an effective media to improve students' mastery in listening. It also supported by Al Jawad \& Mansour (2021) which found that students have positive attitudes in learning listening by using YouTube platform in EFL classroom. The lesson was more interesting than using the traditional media. Hence, students showed their satisfaction in learning listening through this platform. Meanwhile, a previous related research conducted by Mostajeran \& Tabatabaei (2019) revealed that using YouTube to teach listening in the classroom has significant impact on intermediate students in listening comprehension. In addition, they said that YouTube is more effective media than the traditional to teach listening comprehension.

Regarding to the result of questionnaire, students' perception about listening and classroom activities also influence the result of their listening skill. Majority of the students agree that they did not really get difficulties in learning listening. They also satisfied with the teaching media. On the contrary, the previous study by Al Jawad \& Mansour (2021) showed that most of students had lack of motivation and interest in listening. However, YouTube could increase their attention in learning. It can be concluded that even though the students have similar opinion, the innovative media still very influential in improving their score in listening comprehension.

\section{Conclusion}

Based on the results, the researchers concluded that there is significance difference between students taught by YouTube Music and students taught by conventional media related to their score in listening test. The average score of students taught by YouTube Music is 79.85 while the average score that students got by learning with conventional media is 71.50 . The mean difference is 8.346. This different mean is used to assume whether YouTube Music can influence students score to be better or not. After analyzing the significance difference with SPSS tool, the Sig. (2-tailed) is less that $0.05(0.000<0.05)$. It can be inferred that the average score of students taught by YouTube Music is significantly different with students taught by conventional media. It indicates that YouTube Music is an effective media to 
improve students' listening mastery. Besides, the results of questionnaire also contributed to understand if students' perception of learning listening and their satisfaction of the teaching media influence their listening ability.

\section{Suggestion}

It is suggested for EFL teachers, this article can be used as a source to increase knowledge about one of innovative medias and can be implemented for teaching learning activity in the classroom. YouTube Music has been proved as effective media to teach listening skill. For further researchers that want to conduct research with the same field, make development of this research with different aspects that have not already been studied.

\section{References}

Al Jawad, A. S. H., \& Mansour, A. A. (2021). The Significance of Using YouTube as an Academic Tool to Improve Students' Listening Skill in Libyan Universities. International Journal of Linguistics Studies, 1(1), 58-70. https://doi.org/10.32996/ijls.2021.1.1.5

Alimemaj, Z. (2010, May). YouTube Language Learning and Teaching Techniques. The Magazine of Global English Speaking Higher Education, 2 (3), 10-12. Panethnic Limited. http://www.anglohigher.com/magazines/download_pages/61

Burke, S., \& Snyder, S. (2008). YouTube: An Innovative Learning Resource for College Health Education Courses. International Electronic Journal of Health Education, 11(1), 39-46.

Byrne, B. (1986). Self-Concept/Academic Achievement Relations: An Investigation of Dimensionality, Stability, and Causality. Canadian Journal of Behavioural Science, 18, 173-186. https://doi.org/10.1037/h0079982.

Chhabra, P. (2012). Use of E-Learning tools in teaching English. International Journal of Computing \& Business Research, 1-7.

Furotun, N. S., et al. (2021). The Use of Wattpad in English Language Teaching and Learning: Is It Helpful?. JEASP: Journal of English for Academic and Specific Purposes, 4(1), 189-200. https://doi.org/10.18860/jeasp.v4i1.12620

Hasyuni. (2006). The Students' Preferred Activities for English Listening Classes (A Survey Conducted to the Second and Fourth Semester Students of English Department of FKIP Universitas Bengkulu Academic Year 2005/2006). Unpublished Thesis of Teacher Training and Education Faculty of Universitas Bengkulu

Khalid, A., \& Muhammad, K. (2012). The Use of YouTube in Teaching English Literature The Case of Al-Majma'ah Community College, Al-Majma'ah University (Case Study). International Journal of Linguistics, 4(4), 525-551.

Latief, M. A. (2019). Research Methods on Language Learning an Introduction. Malang: Universitas Negeri Malang.

Lee, J. Y., \& Liang, C. J. (2012). Using Video Technology to Diagnose EFL Students Cognitive Learning Difficulties in Public Speaking. International Educational Technology Conference, Procedia- Social Behavioral Sciences, 64, 671- 680. Retrieved on December, 2014, from http://www.sciencedirect.com/science/article/pii/S1877042812050562

Miles, \& Huberman. (1994). Data management and analysis method. London, UK: Sage Publication.Ltd. 
Mostajeran, R., \& Tabatabaei, O. (2019). Impact of Using YouTube Videos on Iranian Intermediate Male and Female EFL Learners' Listening Skill Development. International Journal of Foreign Language Teaching \& Research, 7(28), 75-83. http://jfl.iaun.ac.ir/mobile/article_664513.html

Mustofa, M., \& Sari, A.S. (2020). Video Subtitle to Teach Listening Skill of Junior High School Students. J. Eng. Educ. Society. 5(2). doi: 10.21070/jees.v5i2.874

Nihei, K. (2002). How to Teach Listening. Japan: EDRS.

Oxford, R. L. (1993). Research Update on Teaching L2 Listening. System, 21 (2)

Pradipta, P., \& Mustofa, M. (2020). EFL Learning Via Smart TV in Junior High School. Prosiding Seminar Nasional IKIP Budi Utomo, 1(01), 817-830. https://doi.org/10.33503/prosiding.v1i01.981

Rahman, I.A., et al. (2021). Teaching Literature in A Doll's House Drama. INTERACTION: Jurnal Pendidikan Bahasa, 8(1):73-82. https://doi.org/10.36232/jurnalpendidikanbahasa.v8i1

Reed, M. (2019). Teaching Tip: Listening skills instruction: Practical tips for processing aural input. In J. Levis, C. Nagle, \& E. Todey (Eds.), Proceedings of the 10th Pronunciation in Second Language Learning and Teaching Conference, ISSN 2380-9566, Ames, IA, September 2018 (pp. 401-412). Ames, IA: Iowa State University.

Rost, M. (2013). Listening in Language Learning. New York: Longman.

Saputra, Y. (2018). Changing Students' Perception on Learning Extensive Listening Through YouTube. English Empower: Journal of Linguistics and Literature, 3(1), 41-49. http://www.ejournal.unitaspalembang.ac.id/index.php/eejll/issue/view/May\%202018 